\title{
Article \\ Inkjet Printing Infiltration of the Doped Ceria Interlayer in Commercial Anode-Supported SOFCs
}

\author{
Rumen I. Tomov ${ }^{1, *(\mathbb{D})}$, Thomas B. Mitchel-Williams ${ }^{1}\left(\mathbb{D}\right.$, Eleonora Venezia ${ }^{1}\left(\mathbb{D}\right.$, Michal Kawalec $^{2}$, Mariusz Krauz ${ }^{2}$, \\ Ramachandran Vasant Kumar ${ }^{1}$ and Bartek A. Glowacki ${ }^{1,2}$ \\ 1 Department of Materials Science \& Metallurgy, University of Cambridge, Cambridge CB3 OFS, UK; \\ tbmwilliams@gmail.com (T.B.M.-W.); eleonora.venezia92@gmail.com (E.V.); rvk10@cam.ac.uk (R.V.K.); \\ bag10@cam.ac.uk (B.A.G.) \\ 2 Institute of Power Engineering_-Research Institute, Mory 8, 01-330 Warsaw, Poland; kawalec@cerel.pl (M.K.); \\ krauz@cerel.pl (M.K.) \\ * Correspondence: rit21@cam.ac.uk
}

check for

updates

Citation: Tomov, R.I.;

Mitchel-Williams, T.B.; Venezia, E.;

Kawalec, M.; Krauz, M.; Kumar, R.V.;

Glowacki, B.A. Inkjet Printing

Infiltration of the Doped Ceria

Interlayer in Commercial

Anode-Supported SOFCs.

Nanomaterials 2021, 11, 3095.

https://doi.org/

10.3390/nano11113095

Academic Editor: Graeme Watson

Received: 5 October 2021

Accepted: 8 November 2021

Published: 16 November 2021

Publisher's Note: MDPI stays neutral with regard to jurisdictional claims in published maps and institutional affiliations.

Copyright: (c) 2021 by the authors. Licensee MDPI, Basel, Switzerland. This article is an open access article distributed under the terms and conditions of the Creative Commons Attribution (CC BY) license (https:// creativecommons.org/licenses/by/ $4.0 /)$.

\begin{abstract}
Single-step inkjet printing infiltration with doped ceria $\mathrm{Ce}_{0.9} \mathrm{Ye}_{0.1} \mathrm{O}_{1.95}$ (YDC) and cobalt oxide $\left(\mathrm{Co}_{\mathrm{x}} \mathrm{O}_{\mathrm{y}}\right)$ precursor inks was performed in order to modify the properties of the doped ceria interlayer in commercial $\left(50 \times 50 \times 0.5 \mathrm{~mm}^{3}\right.$ size $)$ anode-supported SOFCs. The penetration of the inks throughout the $\mathrm{La}_{0.8} \mathrm{Sr}_{0.2} \mathrm{Co}_{0.5} \mathrm{Fe}_{0.5} \mathrm{O}_{3-\delta}$ porous cathode to the $\mathrm{Gd}_{0.1} \mathrm{Ce}_{0.9} \mathrm{O}_{2}$ (GDC) interlayer was achieved by optimisation of the inks' rheology jetting parameters. The low-temperature calcination $\left(750^{\circ} \mathrm{C}\right)$ resulted in densification of the Gd-doped ceria porous interlayer as well as decoration of the cathode scaffold with nanoparticles $(\sim 20-50 \mathrm{~nm}$ in size). The I-V testing in pure hydrogen showed a maximum power density gain of $\sim 20 \%$ at $700{ }^{\circ} \mathrm{C}$ and $\sim 97 \%$ at $800{ }^{\circ} \mathrm{C}$ for the infiltrated cells. The latter effect was largely assigned to the improvement in the interfacial Ohmic resistance due to the densification of the interlayer. The EIS study of the polarisation losses of the reference and infiltrated cells revealed a reduction in the activation polarisations losses at $700{ }^{\circ} \mathrm{C}$ due to the nano-decoration of the $\mathrm{La}_{0.8} \mathrm{Sr}_{0.2} \mathrm{Co}_{0.5} \mathrm{Fe}_{0.5} \mathrm{O}_{3-\delta}$ scaffold surface. Such was not the case at $800{ }^{\circ} \mathrm{C}$, where the drop in Ohmic losses was dominant. This work demonstrated that single-step inkjet printing infiltration, a non-disruptive, low-cost technique, can produce significant and scalable performance enhancements in commercial anode-supported SOFCs.
\end{abstract}

Keywords: solid oxide fuel cells; inkjet printing; infiltration; doped ceria; cobalt oxide

\section{Introduction}

Commercial solid oxide fuel cells (SOFCs) provide highly efficient energy conversion, simultaneously offering the additional benefit of combined heat and power generation. One of the attractive properties of high-temperature SOFCs is the ability to use hydrocarbon fuels directly through internal reforming within the fuel cell stack. Such SOFCs typically operate at high temperatures $\left(800-1000^{\circ} \mathrm{C}\right)$ allowing for fuel flexibility [1-8]. One of the important technical challenges operating in this temperature range is the undesirable deterioration and long-term instability due to the chemical interaction between the dissimilar components of the fuel cell stack $[9,10]$. A common approach toward resolving the latter issue is replacing the classical $\mathrm{La}_{1-x} \mathrm{Sr}_{\mathrm{x}} \mathrm{MnO}_{3-\delta}$ (LSM) cathode with mixed ion-electron conductors (MIECs), which were reported to have higher tolerance toward $\mathrm{Cr}$ species compared to LSM electrodes [11,12]. Beneficially, the introduction of MIECs as cathode materials results in an enlargement of the surface active areas involved in the oxygen reduction reaction (ORR [13]). Various MIEC materials, such as $\mathrm{La}_{1-x} \mathrm{Sr}_{x} \mathrm{CoO}_{3-\delta}$ (LSC) [14], $\mathrm{La}_{1-x} \mathrm{Sr}_{x} \mathrm{FeO}_{3-\delta}$ (LSF) [15] or $\mathrm{La}_{1-x} \mathrm{Sr}_{x} \mathrm{Co}_{1-y} \mathrm{Fe}_{y} \mathrm{O}_{3-\delta}$ (LSCF) [16], have been experimented with extensively. LSCF is often used as a material of choice due to a combination of high electronic conductivity and high oxygen ionic conductivity. However, MIECs were found to 
react with Y-stabilised zirconia (YSZ) electrolytes during cell processing, forming deleterious secondary phases, such as $\mathrm{SrZrO}_{3}$ and $\mathrm{La}_{2} \mathrm{Zr}_{2} \mathrm{O}_{7}$ [17]. Moreover, substantial differences in thermal expansion coefficients (TECs) between the MIECs and commercial electrolytes could lead to thermal cycling instability and short SOFC lifetimes [18]. An introduction of a diffusion barrier layer (interlayer) of doped ceria between the YSZ electrolyte and the MIEC cathode is commonly used to alleviate the issue $[19,20]$. Such interlayer has to be thin and dense in order to avoid the addition of an additional Ohmic resistance. Vacuum techniques, such as pulsed laser deposition [21] and magnetron sputtering [22], have been successfully used to deposit efficient dense doped ceria barrier coatings. Unfortunately, the use of vacuum techniques in SOFC processing is considered prohibitively expensive. Commercial SOFCs most often use doped ceria interlayers prepared by the conventional screen-printing technique. The sintering temperatures of the as-deposited interlayer have to be kept below the electrolyte sintering temperatures in order to prevent the formation of an undesirable $\left(\mathrm{Zr}_{1-\mathrm{x}} \mathrm{Ce}_{\mathrm{x}}\right) \mathrm{O}_{2-\mathrm{y}}$ solid solution [23]. This temperature limitation, along with the difference in TECs of doped ceria and doped zirconia, often lead to the formation of porous interlayers. Consequently, diffusion of Sr species is commonly observed, reaching and reacting with the YSZ electrolyte [24]. To resolve the problem, significant efforts were spent on wet nano-chemistry methods, delivering an improved interlayer deposition, e.g., spin coating [25], dip coating [26], spray pyrolysis [27] and electrostatic spray pyrolysis [28], all producing doped ceria interlayers with various degrees of densification. Inkjet printing of suspension inks was also successfully applied for the fabrication of cathode interlayers (LSCF-GDC) [29] as well as a NiO-YSZ_ anode interlayer [30]. Although offering scalability, the above-mentioned techniques often need multistep processing with repeated heat treatments at relatively low deposition rates. The wet-chemical methods, with the exception of inkjet printing, also lead to a certain degree of non-uniformity and are inefficient in terms of ink losses outside the cell area.

Another problem observed at high operational temperatures is the compositional degradation of MIEC cathodes [31-34]. The effect is commonly ascribed to Sr enrichment of the surface, where insulating $\mathrm{SrO},\left(\mathrm{Sr}(\mathrm{OH})_{2}\right.$ and $\mathrm{SrCO}_{3}$ species form and subsequently suppress oxygen surface exchange kinetics [35]. As demonstrated by Rupp et al. [36], a sub-monolayer coverage ( $\sim 4 \%$ of a SrO monolayer) on the LSC thin-film electrode leads to severe deactivation, while a minor decoration with Co oxide ( $2 \%$ of a monolayer) enhances the oxygen exchange rate by $\sim 13 \%$. The co-existence of A- and B-site metal atoms on the surface was shown to have a strong influence on the ORR, with B-site metal atoms (Co or $\mathrm{Fe}$ ) being more reactive than A-site atoms ( $\mathrm{La}$ or $\mathrm{Sr}$ ) [37]. Nanoengineering of perovskite cathodes by infiltration has been actively researched in recent years. Improved performances and stability of the LSCF-based cathodes were demonstrated via decoration of the porous cathode scaffolds with nanoparticles (e.g., noble and transition metal oxides, doped and un-doped ceria, MIEC compounds, etc.). Nano-decoration of screen-printed $\mathrm{La}_{0.8} \mathrm{Sr}_{0.2} \mathrm{Co}_{0.5} \mathrm{Fe}_{0.5} \mathrm{O}_{3-\delta}$ (LSC8255) with $\mathrm{Gd}_{0.2} \mathrm{Ce}_{0.8} \mathrm{O}_{2}$ [38] and tape-casted $\mathrm{La}_{0.6} \mathrm{Sr}_{0.4} \mathrm{Co}_{0.2} \mathrm{Fe}_{0.8} \mathrm{O}_{3-\delta}$ (LSCF6428) cathodes with $\mathrm{Sm}_{0.2} \mathrm{Ce}_{0.8} \mathrm{O}_{1.95}$ (SDC) [39] was reported to reduce the polarisation resistance between two and four times at $750{ }^{\circ} \mathrm{C}$. Dual infiltration of both doped ceria and $\mathrm{Co}_{\mathrm{x}} \mathrm{O}_{\mathrm{y}}$ inks was shown to deliver a synergetic effect, improving both the catalytic activity as well as the performance durability via suppression of the $\mathrm{Co}_{\mathrm{x}} \mathrm{O}_{\mathrm{y}}$ nanoparticle aggregation [40]. $\mathrm{Co}_{\mathrm{x}} \mathrm{O}_{\mathrm{y}}$ nanoparticles were found to serve multiple functions - to act as a sintering aid, improving the densification of doped ceria [41,42], to accelerate adsorption-dissociation-surface exchange reactions of oxygen and to suppress Sr precipitation on the surface of LSCF cathodes [43].

This study focuses on the use of dual infiltration via a non-disruptive scalable technique, namely inkjet printing infiltration (IJI), for improving the performance of commercial anode-supported SOFCs $\left(50 \times 50 \times 0.5 \mathrm{~mm}^{3}\right.$ in size). Yttrium-doped ceria (YDC) ink was jetted in nano-litre-volume drops impinging with high velocity on the surface of the LSCF cathodes. The momentum of the drops forced a sufficient amount of ink to reach the interface between the electrolyte and the cathode, depositing it into the pores of the inter- 
layer. A second infiltration with $\mathrm{Co}_{\mathrm{x}} \mathrm{O}_{\mathrm{y}}$ ink was applied in order to promote the sintering behaviour of the infiltrated doped ceria as well as to enhance the catalytic activity of the infiltrated cathode scaffold. The influence of such nano-infiltration on the electrochemical performance was studied, taking into account the changes in both the Ohmic resistance of the $\mathrm{Ce}_{0.9} \mathrm{Gd}_{0.1} \mathrm{O}_{1.95}$ (GDC) interlayer and the polarisation resistance of the LSCF cathode. A single-step infiltration, leading to low overall infiltrate-loading levels, was implemented in order to avoid blocking of the porous gas channels and introduction of additional concentration polarisation losses.

\section{Materials and Methods}

The choice of inks and infiltration technique used in the experiment was based on our previous works on the synergy effect of dual infiltrations in MIEC cathodes $[40,43,44]$. Such dual infiltration (e.g., doped ceria and $\mathrm{Co}_{\mathrm{x}} \mathrm{O}_{\mathrm{y}}$ ) was shown to enhance the MIEC cathode performance and improve the long-term stability via suppression of $\mathrm{Sr}$ segregation. The goal of this work was to achieve a non-disruptive transfer of the IJI to commercial SOFC processing, contributing to the densification of the doped ceria interlayer and the enhancement of the cathode performance.

Adversely, overloading of the porous cathode scaffold with infiltrate ink is prone to lead to an increase in concentration losses as well as to effective degradation of the LSCF cathode performance. The latter is caused by the partial masking of the active surface area by nano-decorations possessing lower catalytic efficiency. Thus, we attempted to achieve the desired SOFC performance enhancement using minimum amounts of inks delivered by the IJI method with high precision and uniformity as well as no wastage.

The infiltration of active precursors in SOFC electrodes is commonly done in multiple steps (depending on the desired loading levels) followed by low-temperature $\left(<800{ }^{\circ} \mathrm{C}\right)$ calcination. To achieve the desired loading, deeper penetration and more uniform distribution, some research groups perform vacuum treatments after each infiltration step. The infiltrate inks are also often tailored with surfactants and gelling agents in order to attain control over the phase and morphology of the nano-decoration-particle size, distribution, coverage, etc. Tuning the wetting properties of the ink with organic solvents is another efficient way to achieve uniform nano-decoration after calcination. The infiltration procedures reported in the literature have been predominantly performed in a laboratory environment using sample immersion or micro-pipetting. Such procedures are wasteful, slow and not scalable. Several attempts to scale up the process, making it feasible for conventional SOFC technology, have been reported. Lee et al. [45] implemented foam rollers to introduce the inks in the porous anode functional layer. Kiebach et al. [46] "flashed" the infiltrate metal nitrates solutions through the manifold compartments of the SOFC stacks. Spraying the cathode surface with an atomising nozzle was successfully reported by Dowd et al. [47]. All of these approaches achieved scalability at the expense of significant amounts of wasted ink, while having limited control over the uniformity of the infiltration process. In contrast, the inkjet printing infiltration method offers uniform delivery of precisely positioned small droplets (nano-litre volumes) at high rates $(\mathrm{kHz})$ over large surfaces with high lateral resolution. It is inherently cost effective and environmentally friendly due to minimisation of the ink amount used and the lack of wastage. Commercial inkjet printing systems are widely available, ranging from laboratory-scale systems to industrial high-throughput machines. A scalable, low-cost, uniform infiltration was reported by Mitchell-Williams et al. [48] using inkjet printing to infiltrate GDC into 8YSZ SOFC anodes. Attempts to use commercial valve jet technology for the production of SOFC components (anodes and electrolytes) was reported by Tomov et al. [49] and Wang et al. [50]. Tomov et al. [43] also used inkjet printing infiltration to infiltrate GDC into LSCF/GDC composite cathodes. Figure 1 illustrates the customised inkjet printing system, developed in-house, allowing for printing over a large surface area with high throughput. The 16-nozzle Domino valve-jet print head used in this work is shown in the inset. The effective width of the printed single pass was $\sim 40 \mathrm{~mm}$. The commercial anode-supported SOFC shown in the second inset had 
an effective cathode area of $40 \mathrm{~mm} \times 40 \mathrm{~mm}$, which allowed for completing the infiltration run with a single pass of the print head.

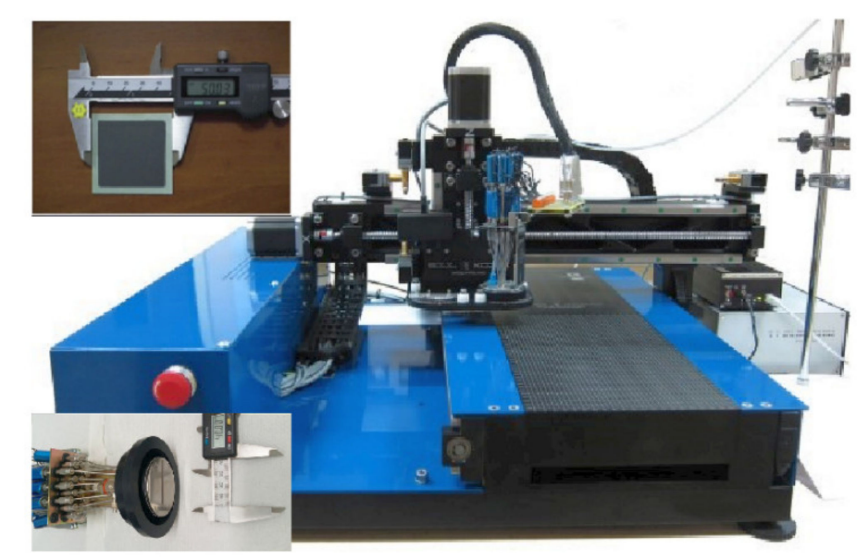

Figure 1. Customised inkjet printing system used for the infiltration experiment (the insets show the 16-nozzle Domino valve-jet print head and the commercial anode-supported SOFC).

\section{Experimental Section}

\subsection{Anode-Supported SOFC Preparation}

Commercially available anode-supported SOFCs (CEREL, Boguchwała, Poland) with screen-printed LSCF cathodes were infiltrated by IJI with doped ceria and cobalt oxide precursor inks. The anode supports were made using high-pressure injection-moulding. A functional layer (8YSZ+NiO-1:1) and an electrolyte layer (8YSZ) were applied using screen printing. After drying, the coatings were sintered at $1400{ }^{\circ} \mathrm{C}$ for $3 \mathrm{~h}$. Then, a GDC interlayer was deposited by screen printing and sintered at $1350{ }^{\circ} \mathrm{C}$ for $1 \mathrm{~h}$. A $\mathrm{La}_{0.6} \mathrm{Sr}_{0.4} \mathrm{Co}_{0.2} \mathrm{Fe}_{0.8} \mathrm{O}_{3-\delta}$ cathode (LSCF thickness $\sim 25 \mu \mathrm{m}$, porosity $\sim 25 \mathrm{vol} \%$ ) was screenprinted and sintered at $1100{ }^{\circ} \mathrm{C}$ for $1 \mathrm{~h}$. In the as-prepared $50 \times 50 \times 0.5 \mathrm{~mm}^{3}$ cells, a 5 - $\mu$ m-thick YSZ electrolyte was supported by a Ni-YSZ cermet anode (including an anode functional layer). The LSCF cathode with an effective area of $16 \mathrm{~cm}^{2}$ was separated from the electrolyte by a thin GDC interlayer ( 2-3 $\mu \mathrm{m}$ thick). A current-conducting LSM coating was applied on the top of LSCF before testing. A detailed description of the anode-supported SOFC manufacturing can be found elsewhere [51].

\subsection{Infiltrate Ink Synthesis}

$\mathrm{Ce}_{0.9} \mathrm{Ye}_{0.1} \mathrm{O}_{1.95}$ (YDC) precursor solutions were prepared by diluting stoichiometric quantities of cerium nitrate hexahydrate $(99.999 \%$, Alfa Aesar, Heysham, UK) and yttrium nitrate hexahydrate $(99.9 \%$ Alfa Aesar) in absolute ethanol. Urea $(>99.5 \%$, Thermo Fisher Scientific, Heysham, UK) was added as a complexing agent in a 1:1.5 molar ratio (metals:urea). For the $\mathrm{Co}_{\mathrm{x}} \mathrm{O}_{\mathrm{y}}$ ink, the precursor ink was prepared in a similar manner using cobalt nitrate hexahydrate (99\%, VWR, Lutterworth, UK) and urea. The powders were dissolved with stirring and heating at $40{ }^{\circ} \mathrm{C}$. The solutions were cooled to room temperature before being passed through a $3 \mu \mathrm{m}$ glass fibre filter.

\subsection{Jetting Optimisation}

The jetting behaviour of a print-head nozzle is generally described with the help of dimensionless Reynolds $(R e)$, Weber $(W e)$ and Ohnesorge $(O h)$ numbers [52]: $R e=\frac{\rho u_{0} r_{0}}{\mu}$; $W e=\frac{\rho u_{0}^{2} r_{0}}{\gamma}$; and $O h=\frac{W e^{0.5}}{R e}$, where $u_{0}, r_{0}, \rho, \mu$ and $\gamma$ denote the drop velocity, drop radius, ink specific mass density, ink viscosity and surface tension coefficient, respectively. Derby et al. $[53,54]$ defined the optimal condition of jetting without splashing or formation of satellite drops as $20>Z>1$ (where $Z=1 / O h$ ). Tuning the jetting parameters to optimum values requires knowledge of the drop velocity and the drop volumes specific for any particular ink and print head. The use of an integrated drop visualisation system allows 
examination of the drops volumes and velocities and assessment of the correct working parameters window. Such optimisation for the electromagnetic (valve jet) print heads was done by varying the opening times and nozzle pressures using an in-house-developed visualisation system, as described elsewhere [48]. This allowed us to achieve optimal drop formation and nearly identical loading for each of the inks used.

According to the numerical model developed by Reis et al. [55] spreading and penetration of the drop into a porous medium is governed by a set of parameters, including the Reynolds number $(R e)$, Weber number $(W e)$, porosity $(\varepsilon)$ and contact angle $(\theta)$. Thus, ink penetration (depth and lateral spreading) is a complex function of fixed parameters $(\varepsilon)$, parameters with variability restricted by the rheological window of stable jetting for a particular ink $(\rho, \mu, \gamma$ and $\theta)$ and sufficiently variable parameters $\left(u_{0}, r_{o}\right)$. Hence, in this study, optimisation of $u_{o}$ and $r_{o}$ was performed, aiming at the formation of small nano-size drops with similar volumes and impingement velocity while simultaneously preserving stable jetting without the formation of satellites or splashing. The uniformity of the drop delivery and cumulative volume of ink infiltrated was governed by the choice of the X-Y step size and the drops' overlap distance.

\subsection{Inkjet Printing Infiltration}

The cathodes of the AS-SOFC (NiO-8YSZ/8YSZ/GDC/LSCF) were infiltrated by inkjet printing of the precursor inks using a commercial 16-nozzle Domino Macrojet print head. The infiltrations were performed using optimised jetting parameters for each ink, as shown in Table 1. The inks were deposited onto the cathode surface at room temperature with drop volumes of approximately $\sim 60 \mathrm{~nL}$ and drop velocities of $\sim 1.5 \mathrm{~m} \mathrm{~s}^{-1}$. Several infiltration passes were performed across the entire surface in a square array pattern with a spacing of $1 \mathrm{~mm}$ between drops. The cells were dried between the infiltration passes at temperatures high enough to remove the ink solvent but lower than the nitrate salts decomposition point. Thus, the permeation channels were freed for the next ink portion to be absorbed into the porous scaffolds. Figure 2 shows the TGA decomposition data for the YDC and $\mathrm{Co}_{\mathrm{x}} \mathrm{O}_{\mathrm{y}}$ precursor inks (solution, dispersant and metal nitrates).

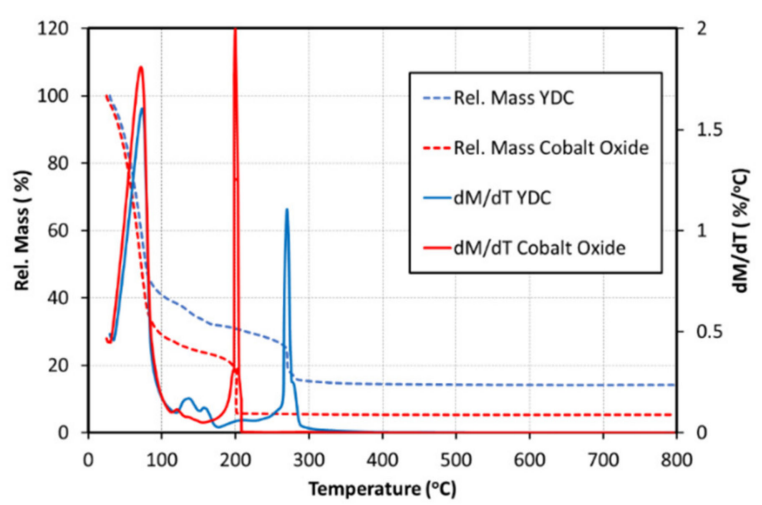

Figure 2. TG curves of $0.75 \mathrm{M}$ YDC and $\mathrm{Co}_{x} \mathrm{O}_{y}$ precursor inks at a $10{ }^{\circ} \mathrm{C} \mathrm{min}^{-1}$ heating rate in air. The final weight losses were used in thickness calculations. Temperature derivatives from the TG analysis clearly pinpoint the temperature range of mass loss.

Temperature derivatives from the TG analysis (DTG) clearly show that the biggest mass loss occurs at $\sim 73-76{ }^{\circ} \mathrm{C}$ where ethanol solvent from both inks is liberated. Above $200{ }^{\circ} \mathrm{C}$, further decomposition results in oxide formation and the release of gases, such as $\mathrm{CO}$ and $\mathrm{CO}_{2}$. There is no further loss observed beyond $300^{\circ} \mathrm{C}$. After the infiltration of the YDC precursor ink, the cells were heated to $500^{\circ} \mathrm{C}$ for $30 \mathrm{~min}$ with heating and cooling rates of $5^{\circ} \mathrm{C} \mathrm{min}{ }^{-1}$. The infiltration of the second ink $\left(\mathrm{Co}_{3} \mathrm{O}_{4}\right.$ precursor ink $\left.\left(62 \mathrm{~nL}, 1.6 \mathrm{~m} \mathrm{~s}^{-1}\right)\right)$ was performed in an identical manner. Samson et al. [56] estimated temperatures above $650^{\circ} \mathrm{C}$ as required for the formation of stable $\mathrm{Co}_{\mathrm{x}} \mathrm{O}_{\mathrm{y}}$ nanoparticles. Due to the necessity to preserve a stable nanostructured interface during testing at temperatures above $700{ }^{\circ} \mathrm{C}$, 
the final-stage calcination was done at $750{ }^{\circ} \mathrm{C}$ in air for $30 \mathrm{~min}$ (heating and cooling rates of $5{ }^{\circ} \mathrm{C} \mathrm{min}-1$ ). The mass loading of each infiltrate was calculated from the weight measurements before and after each infiltration cycle. Loading levels of $\sim 5 \mathrm{wt} \%$ with respect to the LSCF electrode was adjusted for both YDC and cobalt oxide infiltrates.

Table 1. Solution infiltration inks' viscosities and jetting parameters.

\begin{tabular}{lcccccc}
\hline Ink & $\begin{array}{c}\text { Cation } \\
\text { Concentration, } \\
\mathbf{M}\end{array}$ & $\begin{array}{c}\text { Viscosity, } \\
\mathbf{c P}\end{array}$ & $\begin{array}{c}\text { Opening } \\
\text { Time, } \boldsymbol{\mu s}\end{array}$ & $\begin{array}{c}\text { Pressure, } \\
\text { mbar }\end{array}$ & $\begin{array}{c}\text { Drop } \\
\text { Volume, } \\
\text { nL }\end{array}$ & $\begin{array}{c}\text { Drop Velocity, } \\
\text { ms }^{-1}\end{array}$ \\
\hline $\mathrm{YDC}$ & 0.75 & 4.8 & 240 & 200 & 57 & 1.5 \\
$\mathrm{Co}_{\mathrm{x}} \mathrm{O}_{\mathrm{y}}$ & 0.75 & 4.3 & 230 & 225 & 62 & 1.6 \\
\hline
\end{tabular}

\subsection{Characterisation}

The electrochemical performances of the infiltrated and reference AS-SOFCs were tested in a single cell test rig (I-V and electrochemical impedance spectroscopy (EIS) LB2000 current load and VMP3 potentiostat, BioLogic, Seyssinet-Pariset, France) at temperatures of 700 and $800{ }^{\circ} \mathrm{C}$, with pure $\mathrm{H}_{2}$ flow of $1.0 \mathrm{NL} / \mathrm{min}$ acting as fuel feed and standard air flow of $2.0 \mathrm{NL} / \mathrm{min}$ as cathode feed. High-resolution SEM-EDX (Nova NanoSEM, Thermo Fisher Scientific, Waltham, MA, USA) with an acceleration voltage of $15 \mathrm{kV}$ was used for microstructural analysis of the fractured cell's cross sections. Cross sections of the cells were used for elemental mapping. All SEM-EDX analyses presented below were performed post-mortem after completion of the electrochemical testing. Surface chemistries of the bulk and the interfacial areas of the cathodes were characterised using high-resolution X-ray photoelectron spectroscopy (XPS) of wedge-polished samples (K-Alpha ${ }^{+} \mathrm{X}$-ray photoelectron spectrometer, Thermo Fisher Scientific, Waltham, MA, USA). Details about the XPS setup and measurement methodology are reported elsewhere [40].

\section{Results and Discussion}

Drop visualisation optimisation enabled ink-jetting parameters to be tailored in such a way that each triggering event resulted in a single drop of ink, without the formation of satellites. Figure 3 shows the dependence of the centre of mass (CoM) of YDC-EtOH ink drops on the flight delay time. Images of drops superimposed to the relevant delay times showed optimised jetting behaviour. At optimised conditions (200 mbar pressure and an opening time of $240 \mu \mathrm{s}$ ), jetting of a single drop starts with an elongated tail after detaching from the nozzle, which further merges with the main drop and forms a single drop with $\sim 57 \mathrm{~nL}$ volume and $\sim 1.5 \mathrm{~m} \mathrm{~s}^{-1}$ velocity. The CoM in Figure 3 was defined by the imaging software as a centre of mass of the total jetted volume, assuming an ideal symmetry of the drops (or drops) and the tail ejected. The gradually changing size of the circles in Figure 3 illustrated the increasing diameter of the main drop as a result of its merging with the tailing drops into one single volume. Further information about the jet optimisation procedure can be found in the Supplementary Materials as well as in [48]. The descripted optimisation procedure allowed to maximise the drop velocity by adjusting the drop volumes in such a manner that no splashing or satellite drop formation was observed at optimised conditions. No satellite drop formation was observed for both inks, which led to a uniform lateral distribution of the infiltrates. $Z$ numbers of $\sim 10.4$ and $\sim 9.7$ were calculated for $\mathrm{YDC}$ and $\mathrm{Co}_{\mathrm{x}} \mathrm{O}_{\mathrm{y}}$ inks, respectively. Such $\mathrm{Z}$ numbers correspond well with the stable printability window defined by Liu et al. [54] in the region of $1<Z<20$. 


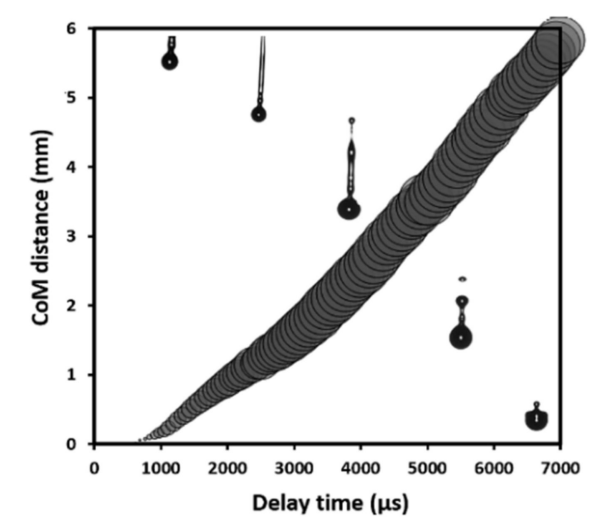

Figure 3. Dependence of the centre of mass (CoM) of jetted drops vs. flight delay time superimposed with the relevant visualisation drop images for the YDC ink.

The differences in the electrochemical performances of the reference and infiltrated cells were expected to be associated with changes in (i) Ohmic $\left(R_{s}\right)$ resistance related to densification of the GDC interlayer, (ii) polarisation $\left(R_{p}\right)$ resistance associated with modification of the catalytic properties of the bulk LSCF scaffold and (iii) introduction of catalytic properties by the infiltrated $\mathrm{Co}_{\mathrm{x}} \mathrm{O}_{\mathrm{y}}$ nanoparticles.

Figure 4 presents the current-potential and current-output power curves measured on the reference and infiltrated cells at $700{ }^{\circ} \mathrm{C}$ and $800{ }^{\circ} \mathrm{C}$. Note that while at $800{ }^{\circ} \mathrm{C}$, the open-circuit voltages (OCVs) of both cells (reference and infiltrated) cells were equal to $1.1 \mathrm{~V}$, at $700{ }^{\circ} \mathrm{C}$, the $\mathrm{OCV}$ of the reference cell was lower (approximately $0.98 \mathrm{~V}$ ). The infiltrated cells showed substantially improved performances in comparison to the reference cell at both temperatures. At $700{ }^{\circ} \mathrm{C}$, the maximum output power increased by approximately $20 \%$, from 330 to $395 \mathrm{~mW} \mathrm{~cm}^{-2}$. The maximum output power density at $800{ }^{\circ} \mathrm{C}$ increased

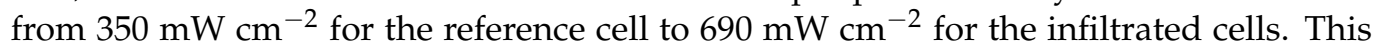
corresponds to a maximum power density gain of $97 \%$ as a result of the infiltration procedure. The EIS data at the OCV for the reference and infiltrated cells recorded at both temperatures is presented in Figure 5. All Nyquist plots had similar shapes consisting of overlapping suppressed semi-circular arcs. As far as the anodes of both cells were identical, the differences between the recorded spectra were ascribed to changes introduced in the cathode and the interlayer by the infiltration procedure. The Ohmic $\left(R_{S}\right)$ resistances were estimated from the intercept of the high-frequency arm of the Nyquist plot with the real axis, while the polarisation resistance $\left(R_{p}\right)$ was estimated as a difference between the lowand high-frequency intercepts. As demonstrated in Figure $5 \mathrm{a}$ at $700{ }^{\circ} \mathrm{C}$, one could observe a drop in the polarisation losses $\left(R_{p}\right)$ related to the substantially lowered high-frequency contribution. Such improvements have been previously assigned to the enhancement of a charge transfer reaction at the extended by the infiltration LSCF/electrolyte interface $[40,57]$. The Ohmic resistance of the infiltrated cells was similar to that of the reference cell. The data collected at $800{ }^{\circ} \mathrm{C}$ suggested a different effect. Although a reduction in $R_{p}$ was observed for the infiltrated cells, it was marginal (see Figure 5b). The shapes of the Bode curves of the reference and infiltrated cells were similar (see the inset in Figure 5b) with a small reduction in $Z^{\prime \prime}$ at lower frequencies $(1-100 \mathrm{~Hz})$ most likely due to enhancement of the surface exchange reaction. This equalisation could be ascribed to the enhanced ORR efficiency of the native LSCF cathode at $800{ }^{\circ} \mathrm{C}$. Thus, the observed substantial power output improvement of infiltrated cells at $800^{\circ} \mathrm{C}$ could be ascribed to the reduction in $R_{s}$, as demonstrated in Figure 5 b. 

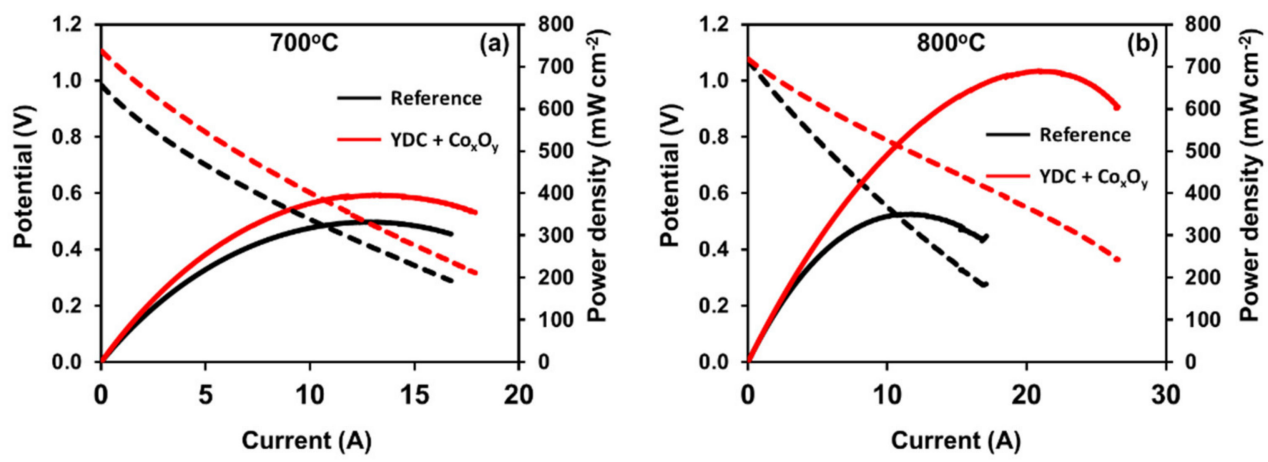

Figure 4. I-V curves and power densities of infiltrated and reference cells measured at (a) $700{ }^{\circ} \mathrm{C}$ and (b) $800{ }^{\circ} \mathrm{C}$.
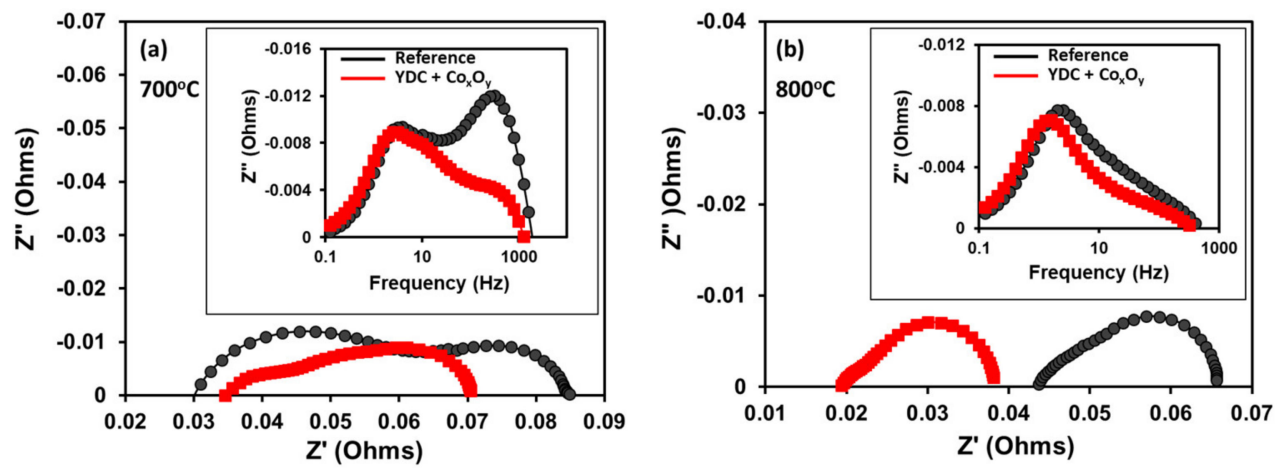

Figure 5. EIS Nyquist plots of infiltrated and reference cells recorded at (a) $700{ }^{\circ} \mathrm{C}$ and (b) $800{ }^{\circ} \mathrm{C}$ (the insets in the figures represent the Bode plots at relevant temperatures).

Looking for proof that the infiltration of $\mathrm{CYO}$ and $\mathrm{Co}_{\mathrm{x}} \mathrm{O}_{\mathrm{y}}$ led to densification of the interfacial GDC interlayer, we performed post-mortem cross-sectional morphological and compositional examination of the cells' cathode bulk as well as cathode-electrolyte interface areas by high-resolution SEM-EDX and XPS.

The post-mortem SEM cross-sectional images of the reference and $\mathrm{YDC}+\mathrm{Co}_{\mathrm{x}} \mathrm{O}_{\mathrm{y}}$ infiltrated commercial cells (see Figure 6) confirmed the densification of the GDC interlayer by the infiltrated nanoparticles, which led to a significant reduction in the interlayer Ohmic resistance contribution. Figure $6 a, c$ depicts the microstructure of the reference and infiltrated cell cross sections of the cathode/interlayer/electrolyte interfaces at lower magnification. The functional interlayer ( 2-3 $\mu \mathrm{m}$ thick) was composed of GDC grains $(\sim 1.0-1.5 \mu \mathrm{m}$ in diameter) with $\sim 50 \%$ porosity. The concentration of infiltrated phases in the interface region was clearly visible, revealing that the interlayer was substantially densified after testing at $800{ }^{\circ} \mathrm{C}$ (see Figure $6 \mathrm{~b}, \mathrm{e}$ ). The images from the area in the middle of the LSCF bulk (see Figure 6f) showed the infiltrated cathode bulk decorated with significantly lower decoration density, consisting of non-percolating nanoparticles. No such nano-decorations were visible on the surface of the non-infiltrated reference cell-see Figure 6c. This indicated that a substantial part of the infiltrate ink penetrates through the porous LSCF scaffold, reaching the GDC interlayer, while some of the ink decorates the surface of the cathode. The EDX maps of the interface areas in the reference and YDC-infiltrated cells are presented in Figure 7a,b, respectively. One can detect the migration of $\mathrm{Sr}$ to the surface of the YSZ electrolyte in both cases. A more localised presence of Sr was seen in the case of the infiltrated cells. 

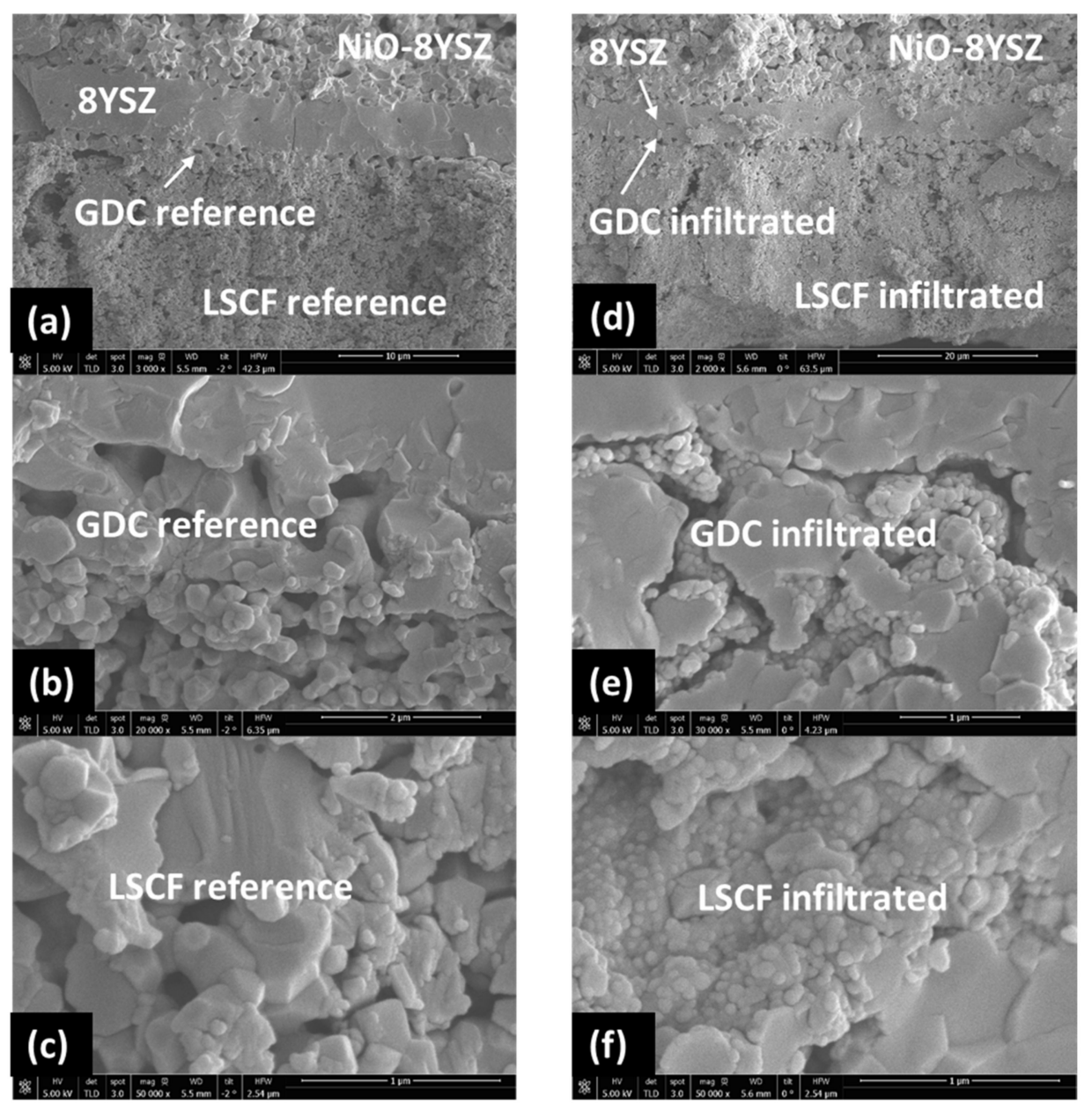

Figure 6. Post-mortem SEM cross-sectional images of the reference cell $(\mathbf{a}-\mathbf{c})$ and the cell infiltrated with YDC and $\mathrm{Co}_{\mathrm{x}} \mathrm{O}_{\mathrm{y}}(\mathbf{d}-\mathbf{f})$. Please note that $(\mathbf{a}, \mathbf{d})$ are low-resolution images of the cross sections of the anode-supported SOFCs, (b,e) are high-resolution images of the GDC interlayer interface areas and $(\mathbf{c}, \mathbf{f})$ are high-resolution images of the LSCF bulk areas. (Note also that the bar sizes on the images signify the following—for image (a), $10 \mu \mathrm{m}$; for image (b), $2 \mu \mathrm{m}$; for image (c), $1 \mu \mathrm{m}$; for image (d), $20 \mu \mathrm{m}$; and for images (e,f), $1 \mu \mathrm{m}$.)

XPS analysis of the bulk and near-interface LSCF areas for the commercial reference and infiltrated cells was performed by careful wedge-type polishing with diamond paste $(1 \mu \mathrm{m})$, as shown in the inset of Figure 8 . Figure 8a-d illustrates the background-corrected core-level XPS spectra of the Ce $3 \mathrm{~d}(\mathrm{a}, \mathrm{b})$, Sr $3 \mathrm{~d}$ (c) and Co $2 p$ (d) bands. The intensity was normalised to the area of the La $3 d_{5 / 2}$ band. The Ce $3 d$ spectra (Figure $8 a, b$ ) showed mainly cerium-doped oxide in the +4 oxidation state, with the characteristic three doublet contributions, namely $(\mathrm{v}, \mathrm{u}),\left(\mathrm{v}^{\prime \prime}, \mathrm{u}^{\prime \prime}\right)$ and $\left(\mathrm{v}^{\prime \prime \prime}, \mathrm{u}^{\prime \prime \prime}\right)$, at positions in good agreement with the literature [58]. As expected, no doped ceria was detected in the reference LSCF bulk cathode (with observable $\mathrm{Co}, \mathrm{Fe}$ and La auger peaks at the Ce $3 \mathrm{~d}$ position), while some amount was registered in the LSCF bulk of the YDC-infiltrated LSCF $\left(\operatorname{La~} 3 d_{5 / 2}:\right.$ Ce $\left.3 d=80: 20\right)$. In contrast, at the interface of the infiltrated electrode, a much higher concentration of doped ceria was registered-La $3 \mathrm{~d}_{5 / 2}$ : Ce $3 \mathrm{~d}=11: 89$. The later observation suggested that a larger portion of the YDC ink was delivered to the area of the GDC/LSCF interface. Additionally, the measured Sr 3d core levels (see Figure 8c) suggested that the amount of $\mathrm{Sr}$ segregated on the cathode surface (detected as $\mathrm{Sr}(\mathrm{OH})_{2}$ and $\mathrm{SrCO}_{3}$ species) was reduced by the infiltration $-S r 3 d_{5 / 2}$ lattice: surface $=43: 57$ for the reference cell and 59:41 for the infiltrated cells. A similar effect of Sr segregation suppression was observed previously by inkjet printing infiltration of GDC into composite LSCF/GDC cathodes in 
symmetric SOFCs [43]. A comparison of the Co $2 p$ core-level spectra between the reference and infiltrated cells is presented in Figure 8d. Both cells exhibited a spectra of a mixed $\mathrm{Co}$ (II) oxide and $\mathrm{Co}$ (III) oxide structure, with the main Co $2 \mathrm{p}_{3 / 2}$ peak located at a BE of $779.4 \mathrm{eV}$ and visible shake-up satellite structures around $786 \mathrm{eV}$ and $789 \mathrm{eV}$ indicative of a mixed $\mathrm{Co}(\mathrm{II})$ and $\mathrm{Co}(\mathrm{III})$ oxide. The excess of $\mathrm{Co}$ in the infiltrated sample was also clearly observable.

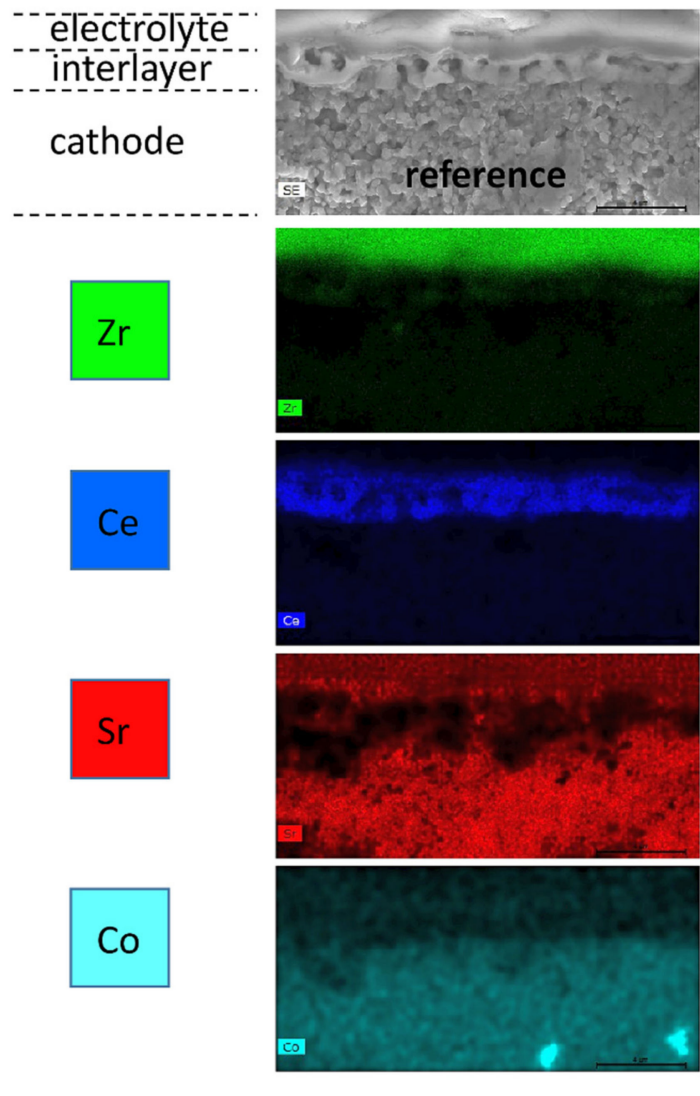

(a)

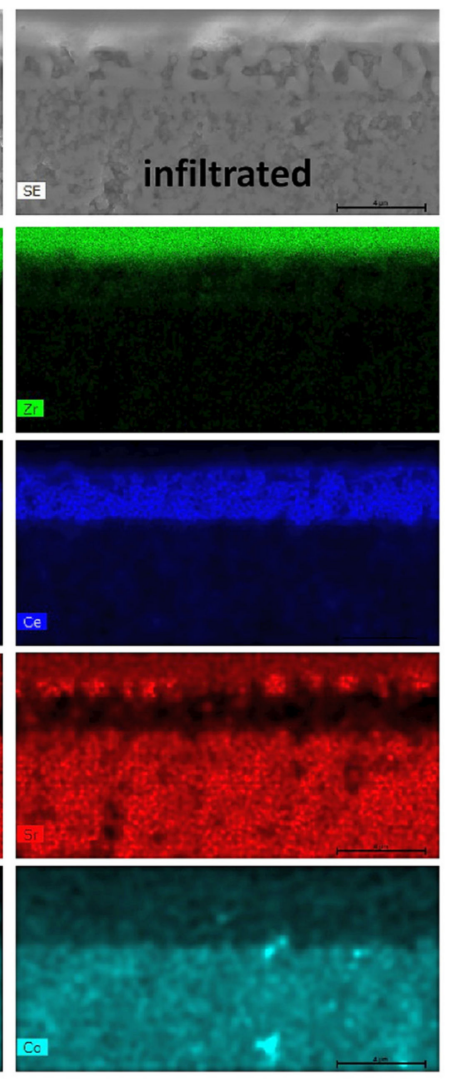

(b)

Figure 7. EDX mapping of the interlayer areas for (a) the reference cell and (b) the infiltrated cell. (Note that the bar size for all images is $4 \mu \mathrm{m}$.)

The presented analyses correlated with the hypothesis that the majority of the infiltrated ink reaches the interface area and the resulting densification of the GDC buffer layer leads to the observed drop in the Ohmic resistance at $800{ }^{\circ} \mathrm{C}$. This demonstrated the efficiency of single-step IJI to deliver the ink to the interlayer location through the porous cathode scaffold. Cobalt oxide has been shown to act as a sintering aid for ceria-based solid solutions by increasing the shrinkage rate at relatively low calcination temperatures [59]. The effect is generally assigned to the formation of a grain-boundary film, providing improved densification routes [60]. Nano-powders possessing a high specific surface area, and thus a high driving force for sintering, experience densification onset at lower temperatures, depending on the $\mathrm{Co}_{\mathrm{x}} \mathrm{O}_{\mathrm{y}}$ doping levels. According to Jud et al., the onset of an enhanced shrinkage rate is observed above $780^{\circ} \mathrm{C}$, with the maximum shrinkage rate at temperatures above $880^{\circ} \mathrm{C}$ [61]. Prasad et al. reported the temperature of the maximum shrinkage rate at $820^{\circ} \mathrm{C}$ for powders synthesised by the deposition-precipitation method [62], which is relevant to the method presented in this work. This can explain why a drop in the Ohmic resistance was observed only at $800{ }^{\circ} \mathrm{C}$, where an effective densification of the interlayer provided additional ion conductive paths, reducing the overall Ohmic resistance. 


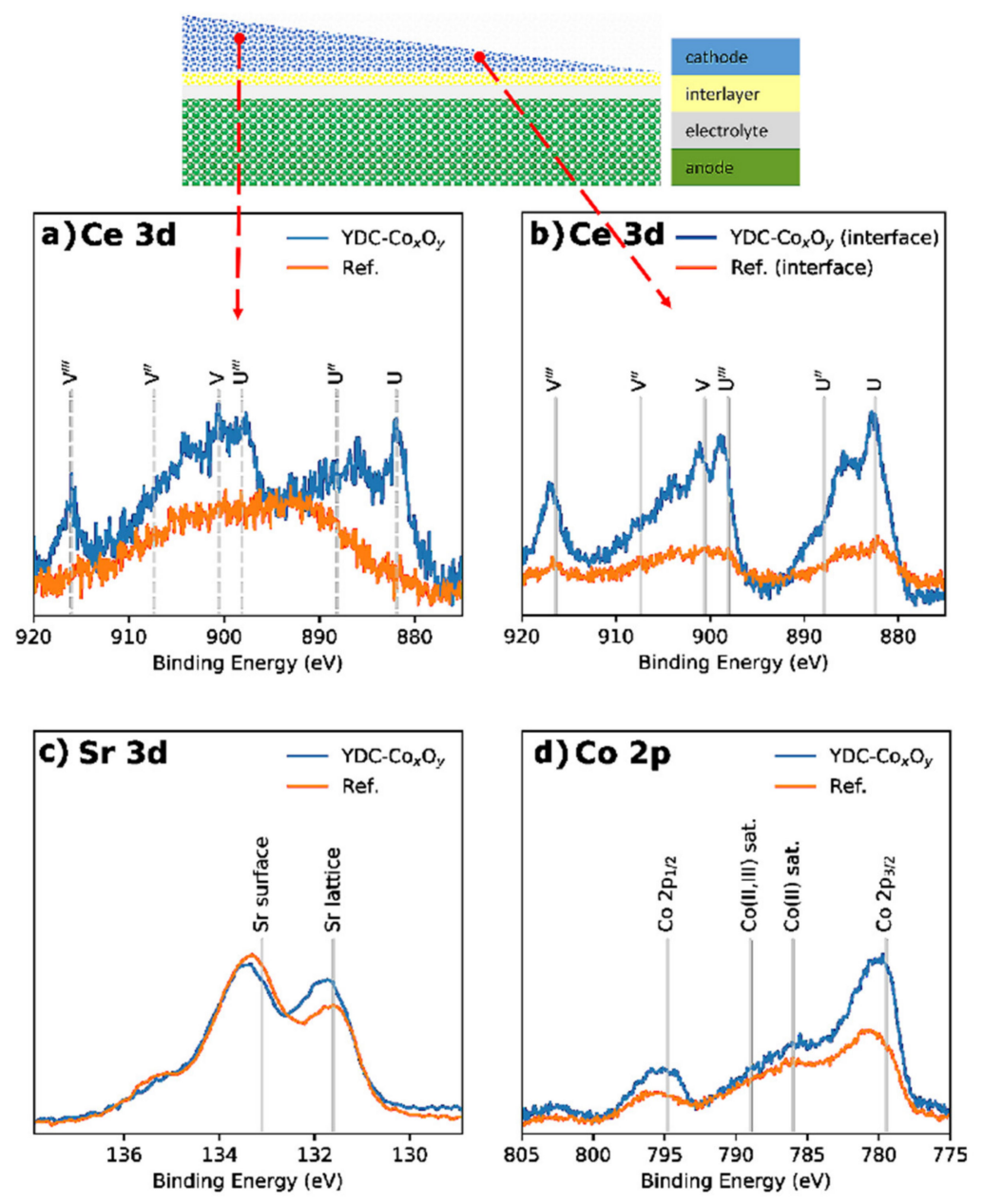

Figure 8. XPS spectra of Ce 3d (a), Sr 3d (c) and Co $2 p(d)$ core levels of the LSCF bulk area and $\mathrm{Ce} 3 \mathrm{~d}$ core level $(\mathbf{b})$ of the near-interface areas for the reference and $\mathrm{YDC}-\mathrm{CO}_{\mathrm{x}} \mathrm{O}_{\mathrm{y}}$ infiltrated cells.

The synergetic effect of doped ceria and $\mathrm{Co}_{\mathrm{x}} \mathrm{O}_{\mathrm{y}}$ co-infiltration led to enhanced densification of the GDC interlayer as well as catalytic contribution of the interface region to the ORR at $800{ }^{\circ} \mathrm{C}$. Despite the non-percolating nature of GDC-Co $\mathrm{O}_{\mathrm{y}}$ nano-decoration, a clear reduction in the polarisation resistance was observed at $700{ }^{\circ} \mathrm{C}$, as evidenced by EIS. A similar effect was reported by Samson et al. [56], who produced cathodes by infiltration of $\mathrm{Co}_{\mathrm{x}} \mathrm{O}_{\mathrm{y}}$ into the porous backbone of GDC and measured an $R_{p}$ of $0.27 \Omega \mathrm{cm}^{2}$ at $600{ }^{\circ} \mathrm{C}$ in air. We speculate that the cause of the observed electrochemical enhancement in this work was related to the nature of the ion exchange between the LSCF bulk cathode and the GDC- $\mathrm{Co}_{\mathrm{x}} \mathrm{O}_{\mathrm{y}}$ nano-decoration. A possible mechanism was proposed by Ding et al. [31], who suggested that the oxygen vacancies $\left(\mathrm{V}_{\mathrm{O}} \bullet \bullet\right)$ prefer to occupy sites next to Co due to the strong $\mathrm{Co}_{\mathrm{o}}-\mathrm{V}_{\mathrm{o}} \bullet \boldsymbol{}^{\bullet}$ binding energy. Therefore, oxygen vacancies' diffusion from LSCF to non-percolating GDC- $\mathrm{Co}_{\mathrm{x}} \mathrm{O}_{\mathrm{y}}$ nanoparticles could enhance the catalytic activity, as observed in the EIS data. The process would reduce the $\mathrm{V}_{\mathrm{o}}{ }^{\bullet}$ concentration in the LSCF sub-surface, hence lowering the surface charge and suppressing $\mathrm{Sr}$ out-diffusion and segregation. In conformation, an experimental study by Druce et al. [63] demonstrated a substantial enhancement of the surface exchange coefficient $\left(k^{*}\right)$ of GDC when coated with $\mathrm{Co}_{3} \mathrm{O}_{4}$. Treatment with Co nitrate was shown to produce an enhancement of $k^{*}$ by approximately an order of magnitude at $700{ }^{\circ} \mathrm{C}\left(k^{*}\right.$ untreated GDC $\left.=1.1 \times 10^{-8} ; k_{\text {coated GDC }}^{*} 1.5 \times 10^{-7}\right)$.

Although studies on cathode nano-engineering by infiltration have been widely published in recent years, to the best of our knowledge, this is the first report on post-processing modification of the doped-ceria interlayer in commercial AS-SOFCs. The simplicity of the combined (doped ceria plus $\mathrm{Co}_{\mathrm{x}} \mathrm{O}_{\mathrm{y}}$ ) inkjet printing infiltration provides encourag- 
ing answers on how to scale up the infiltration procedures via a non-disruptive and cost-saving technique.

\section{Conclusions}

LSCF cathodes and GDC interlayers of commercial anode-supported SOFCs were successfully infiltrated with doped ceria and $\mathrm{Co}_{\mathrm{x}} \mathrm{O}_{\mathrm{y}}$ inks via industrial inkjet printing. The infiltration was done in a single-step procedure without vacuum treatment or intermediate high-temperature calcinations. Relatively low infiltration loading $(\sim 5 \mathrm{wt} \%)$ led to substantially enhanced electrochemical performance. The infiltrated GDC interlayers were densified, which led to a reduction in the overall Ohmic resistance. An improvement in the polarisation resistance was also registered at $700{ }^{\circ} \mathrm{C}$ and assigned to the synergetic catalytic contribution of $\mathrm{Co}_{3} \mathrm{O}_{4}$ / doped ceria infiltration causing beneficial surface modification. Inkjet printing infiltration was demonstrated to be a feasible, non-disruptive and cost-effective technology for infiltration nano-engineering of SOFCs. The combination of high printing speeds, accurate drop delivery, ink conservation and availability of industrial multi-nozzle systems presents an opportunity for scaling up IJI to a commercial-level SOFC technology.

Supplementary Materials: The following are available online at https://www.mdpi.com/article/ 10.3390/nano11113095/s1, Figure S1: Drop visualization optimisation of YDC ink jetting - (a) drop velocity and (b) drop volumes vs. the print head working pressure and nozzles opening time.

Author Contributions: Conceptualisation and methodology, R.I.T. and M.K. (Mariusz Krauz); original draft preparation and editing, R.I.T.; experimentation and testing, R.I.T., T.B.M.-W., E.V., M.K. (Michal Kawalec) and M.K. (Mariusz Krauz); supervision and project administration, R.V.K. and B.A.G. All authors have read and agreed to the published version of the manuscript.

Funding: This research received no external funding.

Data Availability Statement: Not applicable.

Acknowledgments: The authors would like to acknowledge the support of the Ceramic Department CEREL, Institute of Power Engineering, Boguchwała, Poland, for providing commercial SOFCs and testing rig access.

Conflicts of Interest: The authors declare no conflict of interest.

\section{References}

1. Atkinson, A.; Barnett, S.; Gorte, R.J.; Irvine, J.T.S.; McEvoy, A.J.; Mogensen, M.; Singhal, S.C.; Vohs, J. Advanced anodes for high-temperature fuel cells. Nat. Mater. 2004, 3, 17-27. [CrossRef] [PubMed]

2. O'Hayre, R.; Cha, S.W.; Colella, W.; Prinz, F.B. Fuel Cell Fundamentals; Wiley: Hoboken, NJ, USA, 2009.

3. Huang, K.; Goodenough, J.B. Solid Oxide Fuel Cell Technology: Principles, Performance and Operations; Woodhead Publishing Limited: Cambridge, UK, 2009.

4. Irvine, J.T.S.; Neagu, D.; Verbraeken, M.C.; Chatzichristodoulou, C.; Graves, C.; Mogensen, M.B. Evolution of the electrochemical interface in high-temperature fuel cells and electrolysers. Nat. Energy 2016, 1, 15014. [CrossRef]

5. Wachsman, E.D.; Lee, K.T. Lowering the temperature of solid oxide fuel cells. Science 2011, 334, 935-939. [CrossRef] [PubMed]

6. Ormerod, R.M. Solid oxide fuel cells. Chem. Soc. Rev. 2003, 32, 17-28. [CrossRef] [PubMed]

7. Minh, N.Q. Solid oxide fuel cell technology-features and applications. J. Am. Ceram. Soc. 2000, 76, 563-588. [CrossRef]

8. Yamamoto, O. Solid oxide fuel cells: Fundamental aspects and prospects. Electrochim. Acta 2000, 45, 2423-2435. [CrossRef]

9. Steele, B.C.H.; Heinzel, A. Materials for fuel-cell technologies. Nature 2001, 414, 345-352. [CrossRef] [PubMed]

10. Behling, N. Fuel Cells Current Technology Challenges and Future Research Needs, 1st ed.; Elsevier: Amsterdam, The Netherlands, 2013.

11. Jiang, S.P. A comparison of $\mathrm{O}_{2}$ reduction reactions on porous $(\mathrm{La}, \mathrm{Sr}) \mathrm{MnO}_{3}$ and $(\mathrm{La}, \mathrm{Sr})(\mathrm{Co}, \mathrm{Fe}) \mathrm{O}_{3}$ electrodes. Solid State Ion. 2002, 146, 1-22. [CrossRef]

12. McEvoy, A.J. Thin SOFC electrolytes and their interfaces: A near-term research strategy. Solid State Ion. 2000, 132, 159-165. [CrossRef]

13. Fleig, J. On the width of the electrochemically active region in mixed conducting solid oxide fuel cell cathodes. J. Power Sources 2002, 105, 228-238. [CrossRef]

14. Mineshige, A.; Kobune, M.; Fujii, S.; Ogumi, Z.; Inaba, M.; Yao, T.; Kikuchi, K. Metal-insulator transition and crystal structure of $\mathrm{La}_{1-\mathrm{x}} \mathrm{Sr}_{x} \mathrm{CoO}_{3}$ as functions of Sr-content, temperature, and oxygen partial pressure. J. Solid State Chem. 1999, 142, 374-381. [CrossRef] 
15. Simner, S.P.; Bonnett, J.F.; Canfield, N.L.; Meinhardt, K.D.; Sprenkle, V.L.; Stevenson, J.W. Optimized lanthanum ferrite-based cathodes for anode-supported SOFCs. Electrochem. Solid-State Lett. 2002, 5, A173-A175. [CrossRef]

16. Esquirol, A.; Brandon, N.P.; Kilner, J.A.; Mogensen, M. Electrochemical characterization of $\operatorname{La}_{0.6} \mathrm{Sr}_{0.4} \mathrm{Co}_{0.2} \mathrm{Fe}_{0.8} \mathrm{O}_{3}$ cathodes for intermediate-temperature SOFCs. J. Electrochem. Soc. 2004, 151, A1847-A1855. [CrossRef]

17. Kostogloudis, G.C.; Tsiniarakis, G.; Ftikos, C. Chemical reactivity of perovskite oxide SOFC cathodes and yttria stabilized zirconia. Solid State Ion. 2000, 135, 529-535. [CrossRef]

18. Ullmann, H.; Trofimenko, N.; Tietz, F.; Stöver, D.; Ahmad-Khanlou, A. Correlation between thermal expansion and oxide ion transport in mixed conducting perovskite-type oxides for SOFC cathodes. Solid State Ion. 2000, 138, 79-90. [CrossRef]

19. Knibbe, R.; Hjelm, J.; Menon, M.; Pryds, N.; Søgaard, M.; Wang, H.J.; Neufeld, K. Cathode-electrolyte interfaces with CGO barrier layers in SOFC. J. Am. Ceram. Soc. 2010, 93, 2877-2883. [CrossRef]

20. Morales, M.; Miguel-Pérez, V.; Tarancón, A.; Slodczyk, A.; Torrell, M.; Ballesteros, B.; Ouweltjes, J.P.; Bassat, J.M.; Montinaro, D.; Morata, A. Multi-scale analysis of the diffusion barrier layer of gadolinia-doped ceria in a solid oxide fuel cell operated in a stack for 3000 h. J. Power Sources 2017, 344, 141-151. [CrossRef]

21. Chen, D.; Yang, G.; Shao, Z.; Ciucci, F. Nanoscaled Sm-doped $\mathrm{CeO}_{2}$ buffer layers for intermediate-temperature solid oxide fuel cells. Electrochem. Commun. 2013, 35, 131-134. [CrossRef]

22. Sønderby, S.; Klemensø, T.; Christensen, B.H.; Almtoft, K.P.; Lu, J.; Nielsen, L.P.; Eklund, P. Magnetron sputtered gadolinia-doped ceria diffusion barriers for metal-supported solid oxide fuel cells. J. Power Sources 2014, 267, 452-458. [CrossRef]

23. Tsoga, A.; Naoumidis, A.; Stöver, D. Total electrical conductivity and defect structure of $\mathrm{ZrO}_{2}-\mathrm{CeO}_{2}-\mathrm{Y}_{2} \mathrm{O}_{3}-\mathrm{Gd}_{2} \mathrm{O}_{3}$ solid solutions Solid State Ion. 2000, 135, 403-409. [CrossRef]

24. Wang, F.; Nishi, M.; Brito, M.E.; Kishimoto, H.; Yamaji, K.; Yokokawa, H.; Horita, T. Sr and Zr diffusion in LSCF/10GDC/8YSZ triplets for solid oxide fuel cells (SOFCs). J. Power Sources 2014, 258, 281-289. [CrossRef]

25. Plonczak, P.; Joost, M.; Hjelm, J.; Søgaard, M.; Lundberg, M.; Hendriksen, P.V. A high performance ceria based interdiffusion barrier layer prepared by spin-coating. J. Power Sources 2011, 196, 1156-1162. [CrossRef]

26. Hierso, J.; Boy, P.; Vallé, K.; Vulliet, J.; Blein, F.; Laberty-Robert, C.; Sanchez, C. Nanostructured ceria based thin films ( $\leq 1 \mu \mathrm{m})$ as cathode/electrolyte interfaces. J. Solid State Chem. 2013, 197, 113-119. [CrossRef]

27. Szymczewska, D.; Chrzan, A.; Karczewski, J.; Molin, S.; Jasinski, P. Spray pyrolysis of doped-ceria barrier layers for solid oxide fuel cells. Surf. Coat. Technol. 2017, 313, 168-176. [CrossRef]

28. Constantin, G.; Rossignol, C.; Barnes, J.-P.; Djurado, E. Interface stability of thin, dense CGO film coating on YSZ for solid oxide fuel cells. Solid State Ion. 2013, 235, 36-41. [CrossRef]

29. Yashiro, N.; Usui, T.; Kikuta, K. Application of a thin intermediate cathode layer prepared by inkjet printing for SOFCs. J. Eur. Ceram. Soc. 2010, 30, 2093-2098. [CrossRef]

30. Sukeshini, A.M.; Cummins, R.; Reitz, T.; Miller, R.M. Inkjet printing of anode supported SOFC: Comparison of slurry pasted cathode and printed cathode. Electrochem. Solid-State Lett. 2009, 12, B176-B179. [CrossRef]

31. Ding, H.; Virkar, A.V.; Liu, M.; Liu, F. Suppression of Sr surface segregation in $\mathrm{La}_{1-\mathrm{x}} \mathrm{Sr}_{\mathrm{x}} \mathrm{Co}_{1-\mathrm{y}} \mathrm{Fe}_{\mathrm{y}} \mathrm{O}_{3-\mathrm{d}}$ : A first principles study. Phys. Chem. Chem. Phys. 2013, 15, 489-496. [CrossRef] [PubMed]

32. Bucher, E.; Sitte, W. Long-term stability of the oxygen exchange properties of $(\mathrm{La}, \mathrm{Sr})_{1-z}(\mathrm{Co}, \mathrm{Fe}) \mathrm{O}_{3-\delta}$ in dry and wet atmospheres. Solid State Ion. 2011, 192, 480-482. [CrossRef]

33. Wang, H.; Yakal-Kremski, K.J.; Yeh, T.; Rupp, G.M.; Limbeck, A.; Fleig, J.; Barnett, S.A. Mechanisms of performance degradation of $(\mathrm{La}, \mathrm{Sr})(\mathrm{Co}, \mathrm{Fe}) \mathrm{O}_{3-\delta}$ solid oxide fuel cell cathodes. J. Electrochem. Soc. 2016, 163, F581-F585. [CrossRef]

34. Oh, D.; Gostovic, D.; Wachsman, E.D. Mechanism of $\mathrm{La}_{0.6} \mathrm{Sr}_{0.4} \mathrm{Co}_{0.2} \mathrm{Fe}_{0.8} \mathrm{O}_{3}$ cathode degradation. J. Mater. Res. 2012, $27,1992-1999$. [CrossRef]

35. Heide, P.A.W.V. Systematic x-ray photoelectron spectroscopic study of $\mathrm{La}_{1-\mathrm{x}} \mathrm{Sr}_{\mathrm{x}}$-based perovskite-type oxides. Surf. Interface Anal. 2002, 33, 414-425. [CrossRef]

36. Rupp, G.M.; Opitz, A.K.; Nenning, A.; Limbeck, A.; Fleig, J. Real-time impedance monitoring of oxygen reduction during surface modification of thin film cathodes. Nat. Mater. 2017, 16, 640-646. [CrossRef]

37. Wang, Zh.; Peng, R.; Zhang, W.; Wu, X.; Xia, Ch.; Lua, Y. Oxygen reduction and transport on the $\mathrm{La}_{1-x} \mathrm{Sr}_{\mathrm{x}} \mathrm{Co}_{1-\mathrm{y}} \mathrm{Fe}_{\mathrm{y}} \mathrm{O}_{3-\delta} \mathrm{cathode}$ in solid oxide fuel cells: A first-principles study. J. Mater. Chem. A 2013, 1, 12932-12940. [CrossRef]

38. Chen, J.; Liang, F.; Chi, B.; Pu, J.; Jiang, S.P.; Jian, L. Palladium and ceria infiltrated $\mathrm{La}_{0.8} \mathrm{Sr}_{0.2} \mathrm{Co}_{0.5} \mathrm{Fe}_{0.5} \mathrm{O}_{3-\delta}$ cathodes of solid oxide fuel cells. J. Power Sources 2009, 194, 275-280. [CrossRef]

39. Nie, L.F.; Liu, M.F.; Zhang, Y.J.; Liu, M.L. $\mathrm{La}_{0.6} \mathrm{Sr}_{0.4} \mathrm{Co}_{0.2} \mathrm{Fe}_{0.8} \mathrm{O}_{3-\delta}$ cathodes infiltrated with samarium-doped cerium oxide for solid oxide fuel cells. J. Power Sources 2010, 195, 4704-4708. [CrossRef]

40. Tomov, R.I.; Mitchel-Williams, T.B.; Maher, R.; Kerherve, G.; Cohen, L.; Payne, D.J.; Kumar, R.V.; Glowacki, B.A. The synergistic effect of cobalt oxide and Gd-CeO 2 dual infiltration in LSCF/CGO cathodes. J. Mater. Chem. A 2018, 6, 5071-5081. [CrossRef]

41. Pérez-Coll, D.; Marrero-López, D.; Núñez, P.; Piñol, S.; Frade, J.R. Grain boundary conductivity of $\mathrm{Ce}_{0.8} \mathrm{Ln}_{0.2} \mathrm{O}_{2-\delta}$ ceramics $(\mathrm{Ln}=\mathrm{Y}, \mathrm{La}, \mathrm{Gd}, \mathrm{Sm})$ with and without Co-doping. Electrochim. Acta 2006, 51, 6463-6469. [CrossRef]

42. Zhang, T.; Hing, P.; Huang, H.; Kilner, J. Sintering and grain growth of $\mathrm{CoO}-$ doped $\mathrm{CeO}_{2}$ ceramics. J. Eur. Ceram. Soc. 2002, 22, 27-34. [CrossRef]

43. Tomov, R.I.; Mitchell-Williams, T.; Gao, C.; Kumar, R.V.; Glowacki, B.A. Performance optimization of LSCF/Gd:CeO 2 composite cathodes via single-step inkjet printing infiltration. J. Appl. Electrochem. 2017, 47, 641-651. [CrossRef] [PubMed] 
44. Venezia, E.; Viviani, M.; Presto, S.; Kumar, V.; Tomov, R.I. Inkjet Printing Functionalization of SOFC LSCF Cathodes. Nanomaterials 2019, 9, 654. [CrossRef]

45. Lee, K.T.; Yoon, H.S.; Ahn, J.S.; Wachsman, E.D. Bimodally integrated anode functional layer for lower temperature solid oxide fuel cells. J. Mater. Chem. 2012, 22, 17113-17120.

46. Kiebach, R.; Zielke, P.; Høgh, J.V.T.; Thyden, K.; Wang, H.-J.; Barford, R.; Hendriksen, P.V. Infiltration of SOFC stacks: Evaluation of the electrochemical performance enhancement and the underlying changes in the microstructure. Fuel Cells 2016, 16, 80-88. [CrossRef]

47. Dowd, R.P., Jr.; Lee, S.; Fan, Y.; Gerdes, K. Engineering the solid oxide fuel cell electrocatalyst infiltration technique for industrial use. Int. J. Hydrog. Energy 2016, 41, 14971-14981. [CrossRef]

48. Mitchel-Williams, T.B.; Tomov, R.I.; Saadabadi, S.A.; Krauz, M.; Aravind, P.V.; Glowacki, B.A.; Kumar, R.V. Infiltration of commercially available, anode supported SOFC's via inkjet printing. Mater. Renew. Sustain. Energy. 2017, 6, 12. [CrossRef]

49. Tomov, R.I.; Krauz, M.; Jewulski, J.; Hopkins, S.C.; Kluczowski, J.R.; Glowacka, D.M.; Glowacki, B.A. Direct ceramic inkjet printing of yttria-stabilized zirconia electrolyte layers for anode-supported solid oxide fuel cells. J. Power Sources 2010, 195, 7160-7167. [CrossRef]

50. Wang, C.; Hopkins, S.C.; Tomov, R.I.; Kumar, R.V.; Glowacki, B.A. Optimisation of CGO suspensions for inkjet-printed SOFC electrolytes. J. Eur. Ceram. Soc. 2012, 32, 2317-2324. [CrossRef]

51. Kluczowski, R.; Krauz, M.; Kawalec, M.; Ouweltjes, J.P. Near net shape manufacturing of planar anode supported solid oxide fuel cells by using ceramic injection molding and screen printing. J. Power Sources 2014, 268, 752-757. [CrossRef]

52. Derby, B. Inkjet printing of functional and structural materials: Fluid property requirements, feature stability, and resolution. Annu. Rev. Mater. Res. 2010, 40, 395-414. [CrossRef]

53. Derby, B. Inkjet printing ceramics: From drops to solid. J. Eur. Ceram. Soc. 2011, 31, 2543-2550. [CrossRef]

54. Liu, Y.; Derby, B. Experimental study of the parameters for stable drop-on-demand inkjet performance. Phys. Fluids 2019, 31, 032004. [CrossRef]

55. Reis, N.C.; Griffiths, R.F.; Santos, J.M. Parametric study of liquid droplets impinging on porous surfaces. Appl. Math. Model 2008, 32, 341-361. [CrossRef]

56. Samson, A.J.; Søgaard, M.; Bonanos, N. Electrodes for solid oxide fuel cells based on infiltration of co-based materials. Electrochem. Solid-State Lett. 2012, 15, B54-B56. [CrossRef]

57. Burye, T.E.; Nicholas, J.D. Nano-ceria pre-infiltration improves $\mathrm{La}_{0.6} \mathrm{Sr}_{0.4} \mathrm{Co}_{0.8} \mathrm{Fe}_{0.2} \mathrm{O}_{3-\mathrm{x}}$ infiltrated solid oxide fuel cell cathode performance. J. Power Sources 2015, 300, 402-412. [CrossRef]

58. Burroughs, B.P.; Hamnett, A.; Orchard, A.F.; Thornton, G. Satellite structure in the X-ray photoelectron spectra of some binary and mixed oxides of lanthanum and cerium. J. Chem. Soc. Dalt. Trans. 1976, 17, 1686-1898. [CrossRef]

59. Jud, E.; Gauckler, L.J. Sintering behavior of cobalt oxide doped ceria powders of different particle sizes. J. Electroceram. 2005, 14, 247-253. [CrossRef]

60. Kleinlogel, C.; Gauckler, L.J. Sintering and properties of nanosized ceria solid solutions. Solid State Ion. 2000, 135, 567-573. [CrossRef]

61. Jud, E.; Gauckler, L.; Halim, S.; Stark, W. Sintering behavior of in situ cobalt oxide-doped cerium-gadolinium oxide prepared by flame spray pyrolysis. J. Am. Ceram. Soc. 2006, 85, 2970-2973. [CrossRef]

62. Prasad, D.H.; Park, S.Y.; Ji, H.; Kim, H.-R.; Son, J.-W.; Kim, B.-K.; Lee, H.-W.; Lee, J.-H. Cobalt oxide co-doping effect on the sinterability and electrical conductivity of nano-crystalline Gd-doped ceria. Ceram. Int. 2012, 38S, S497-S500. [CrossRef]

63. Druce, J.; Kilner, J.A. Improvement of oxygen surface exchange kinetics for CGO with surface treatment. J. Electrochem. Soc. 2014, 161, F99-F104. [CrossRef] 